\title{
An approach to design, In silico predictions and molecular docking studies of 1,3,4-oxadiazolyl sulphonamides as possible inhibitors of bacterial Mur enzymes, the amino acid ligases in peptidoglycan synthesis
}

\author{
B. HASEENA BANU* \\ Krishna Teja Pharmacy College, Affiliated to JNTUA, Chadalawada Nagar, Renigunta Road, Tirupati, AP, India
}

Received: 13 November, 2017; Accepted: 07 December, 2017; Published: 11 December, 2017

*Corresponding author: B. HASEENA BANU, Krishna Teja Pharmacy College, Affiliated to JNTUA, Chadalawada Nagar, Renigunta Road, Tirupati, AP, India, Tel: 9949640769; E-mail: luckyaftab2002@gmail.com

\begin{abstract}
The extensive use of antibiotics in hospitals and community since their introduction into medical practice has created major evolutionary pressures in bacteria to develop various resistance mechanisms. This phenomenon has led to increased morbidity, mortality and health care costs. The search for new antibacterial agents directed towards novel targets became highly imperative. The biosynthetic pathway of cytoplasmic peptidoglycan precursor is currently gaining much interest as a target site for antibacterial therapy. Since the mid1990s, many inhibitors of the Mur cytoplasmic enzymes have been reported, but none has yet led to the development of a clinically utilized therapeutic agent. In view of the potentiality of sulphonamide and 1,3,4-oxadiazole moieties, it was planned to incorporate both the scaffolds. Thus a series of 4-Amino- N-[(5- phenyl-1,3,4- oxadiazol2-yl)methyl] substituted benzene-1- sulfonamides (1-10) were designed, predicted for molecular properties and docking studies were conducted on Mur enzymes. The presence of the two pharmacophoric scaffolds, oxadiazole and sulphonamide influenced the good bioactive scores. Docking studies further supported the biological activities. The results indicated the possible inhibitory activity towards the Mur enzymes. The results also indicate the selectivity towards Mur A, Mur C, \&amp; Mur E enzymes. Of all the compounds, compound 6 and compound 9 with isopropyl substitution exhibited the highest scores against all the three Mur enzymes. Compound 7 showed good binding interactions with Mur C and Mur E.
\end{abstract}

\section{Abbreviations}

Alr: Alanine Racemase

Ddl: D-Ala-D-Ala Ligases

GPCR: G-Protein-Coupled Receptor

IUPAC: The International Union of Pure And Applied Chemistry

Mur A Udp-N-Acetylglucosamine Enolpyruvyltransferase

Mur B Udp-N-Acetylenolpyruvylglucosamine Reductase

Mur C- N-Acetylmuramate L-Alanine Ligase

Mur D- N-Acetylmuramoyl-L-Alanine D-Glutamate Ligase
Mur E - N-Acetylmuramoyl-L-Alanyl-D-Glutamate MesoDiaminopimelate Ligase

PASS: Prediction Of Activity Spectra For Biologically Active Substances.

PDB ID-Protein Data Bank-Identification

QSAR: Quantitative Structure Activity Relationship

Rtob: Rotatable Bonds

SAR: Structure Activity Relationship

SD File: Structure Data File

SMILES: Simplified Molecular-Input Line-Entry System

TPSA: Topological Polar Surface Area

UDP : Uridine Diphosphate

\section{Introduction}

The treatment of microbial infections still remains an important and challenging medical problem. Sulfonamides (sulfa drugs) were the first drugs largely employed and systematically used as preventive and chemotherapeutic agents against various diseases [1]. Over 30 drugs containing this functionality are in clinical use, including antihypertensive agent bosentan, antibacterial, antiprotozoal, antifungal, antiinflammatory, lipoxygenase inhibitor, nonpeptidic vasopressin receptor antagonists and translation initiation inhibitors [2-8].

The literature is enriched with excellent antimicrobial activity for compounds containing the 2,5-substituted 1,3,4-oxadiazole core [9-11]. Oliveira and co-workers reported synthesis and anti-staphylococcal activity of 1, 3, 4-oxadiazolines against strains of S.aureus, resistant to methicillin and amino glycosides and that encode efflux proteins (multidrug drugs resistantMDR more active than the standard drug chloramphenicol [12]. The antibacterial and antifungal activity of 2-(5-amino-1,3,4oxadiazol-2-yl)-4-bromophenol and 5-(3,5-dibromophenyl)- 
1,3,4-oxadiazol-2-amine were investigated against grampositive bacteria, gram-negative bacteria and fungal species approximately equal to the standard drugs of treatment streptomycin and Griseofulvin [13]. 2,5-disubstituted 1,3,4 oxadiazoles were reported as potent antibacterial and antifungal agents [14](Figure 1).

Despite of the development of several new antimicrobial agents, their use has been clinically limited due to bacterial resistance and pharmacokinetic insufficiencies [15]. The aim of the research was to target the biosynthetic pathway of cytoplasmic peptidoglycan, which is currently gaining much interest as a target site for antibacterial therapy and provides good prospects for discovering selective bacterial inhibitors [16]. Therefore, it prompted us to design the new molecules in such a way that the basic pharmacophoric scaffolds were conjugated with each other, sulfonamide moiety at $2^{\text {nd }}$ position of 1,3,4-oxadiazol ring and phenyl ring at position 5 , altered by varying substituents on phenyl ring. These compounds were predicted molecular properties and drug likeness scores, compared the effect of different substitutions in the pharmacophore on the drug likeness properties. Molecular docking studies of the compounds on Mur enzymes were conducted for ensuring the possibility of mechanism of action.

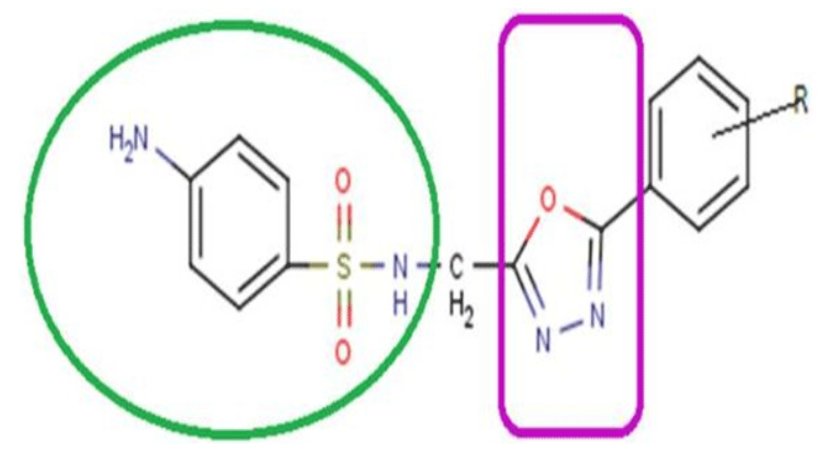

1, 3, 4-oxadiazolyl sulphonamides

Figure 1: Design of new compounds by conjugation of sulfonamide and 1,3, 4-oxadiazole moieties

\section{Methodology}

The structural analogue based drug design has been performed using MARVIN SKETCH, in which molecules insilico drug likeness and molecular property prediction tool are important the new molecules, designed on the basis of SAR and pharmacophore study, were then imported into JME molecular editor to allow different properties to be calculated.

\section{Preparation of Mol and Mol2 files}

The chemical structures drawn were saved in the Mol and Mol2 formats using Chemaxon software (www.chemaxon.com).

\section{Prediction of molecular properties from chemical structure}

Chemicalize is a free chemical structure miner and web search engine developed and owned by ChemAxon. The main purpose of chemicalize.org is to identify chemical names
(SMILES, traditional and IUPAC names) on websites and convert them to chemical structures. chemicalize.org provides other services such as structure based predictions, chemical search, and a "chemicalized" web search (www.chemicalize.org).

Molinspiration offers broad range of cheminformatics software tools supporting molecule manipulation and processing, including SMILES and SDfile conversion, normalization of molecules, generation of tautomers, molecule fragmentation, calculation of various molecular properties needed in QSAR, molecular modeling and drug design, high quality molecule depiction, molecular database tools supporting substructure and similarity searches. Our products support also fragment-based virtual screening, bioactivity prediction and data visualization. Molinspiration tools are written in Java, therefore can be used practically on any computer platform (www.molinspiration.com).

Molsoft offers software tools and services in lead discovery, modeling, chem-informatics, bioinformatics, and corporate data management; and forms partnerships with biotechnology and pharmaceutical companies. For many years Molsoft is building unique technologies for structure prediction and is increasing our understanding of spatial organization of biological molecules and their interactions with each other, their biological substrates and drug-like molecules at atomic level (www.molsoft.com).

\section{Selection of targets}

The synthesis of the pentapeptide chain is facilitated by enzymes of the Mur pathway and involve MurA-F the D-AlaD-Ala ligases (Ddl) and alanine racemase (Alr). MurA and -B convert UDP-N-acetylglucosamine into UDP-N-acetylmuramic acid, the nucleotide sugar used by the ligases MurC-F to produce the pentapeptide chain which is later transferred across the cytoplasmic membrane to be incorporated in the growing cell wall [16]. In contrast to well established approaches exploiting the later stages of prostaglandin synthesis (the discovery and development of $\beta$-lactam and glycopeptide antibiotics) structurebased approaches were used for the design and synthesis of selective inhibitors of early stage Mur enzymes(Figure 2).

\section{Molecular Docking Studies}

Docking calculations have been applied in pharmaceutical research for nearly two decades. Computational approaches that 'dock' small molecules into the structures of macromolecular targets and 'score' their potential complementarily to binding sites are widely used in hit identification and lead optimization. Indeed, there are now a number of drugs whose development was heavily influenced by / or based on structure-based design and screening strategies [18].

The docking process involves the prediction of ligand conformation and orientation (or posing) within a targeted binding site. In general, there are two aims of docking studies: accurate structural modeling and correct prediction of activity by the identification of molecular features responsible for specific biological recognition, or the prediction of compound modifications that improve potency [19]. 


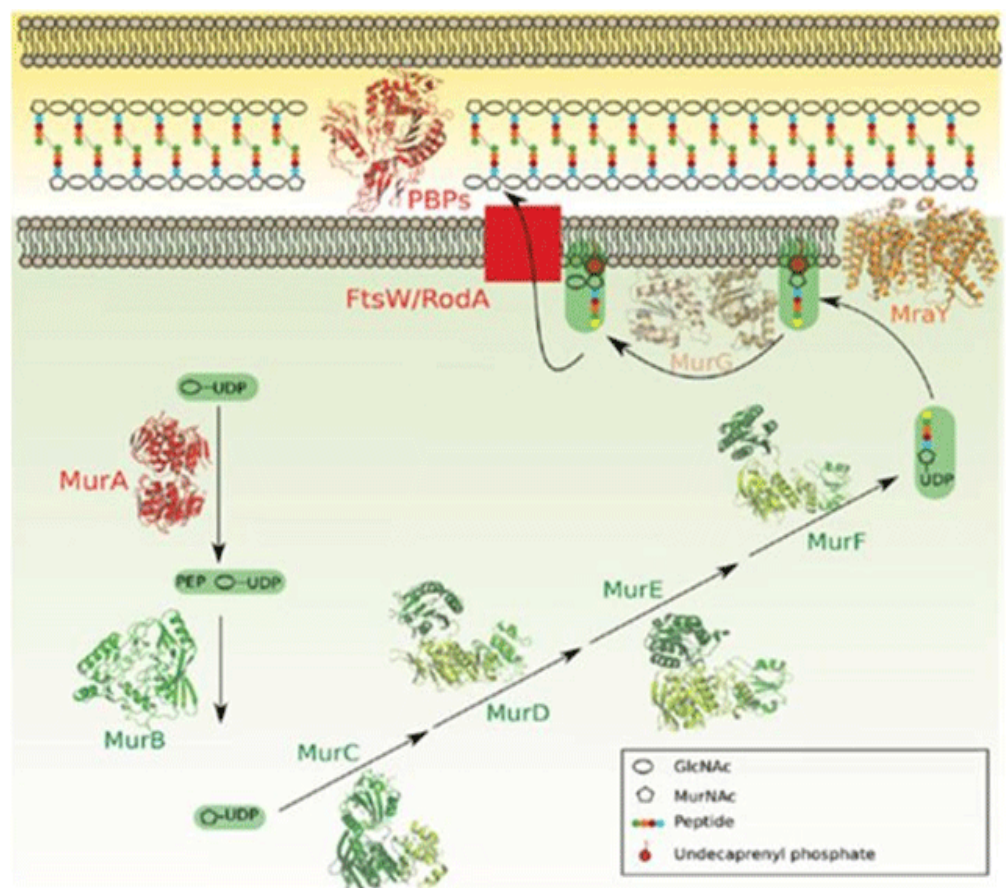

Figure 2: The cytoplasmic steps of peptidoglycan biosynthesis catalyzed by Mur enzymes

In order to rationalize the different biological results shown and bioactivity score predictions and PASS predicted values obtained for active compounds in each series, molecular docking studies were performed using SWISS dock software.

\section{Results and Discussion}

\section{Design and nomenclature}

Prompted by the medicinal importance of 1,3,4-oxadiazolyl and sulfonamide moieties, the structural analogues of oxadiazolyl sufonamides were designed in such a way that, the analogues have both biological active moieties.

The structural analogues have been designed in such a way that it will show more drug likeness score than the prototype molecule but having the same pharmacophore essential for the activity. A series of ten 4-amino-N-[(5-phenyl-1,3,4-oxadiazol-2yl)methyl] substituted benzene-1-sulfonamides were designed and their chemical structures were drawn using Marvin sketch.

Different substituents such as electron donating (chloro, isopropyl, tert-butyl), electron releasing (hydroxyl, methoxy, nitro) etc were substituted on the benzene ring to study their effect on the predicted properties and also biological activities.

The list of designed analogues with drug likeness scores, and other molecular properties have been listed below. The position of substituent on benzene ring was modified in these designed molecules to get increased drug likeness score. Table 1 gives the information about different substituted compounds and table 2 indicates the nomenclature generated using soft ware chemicalize.org (Table 1, Table 2).

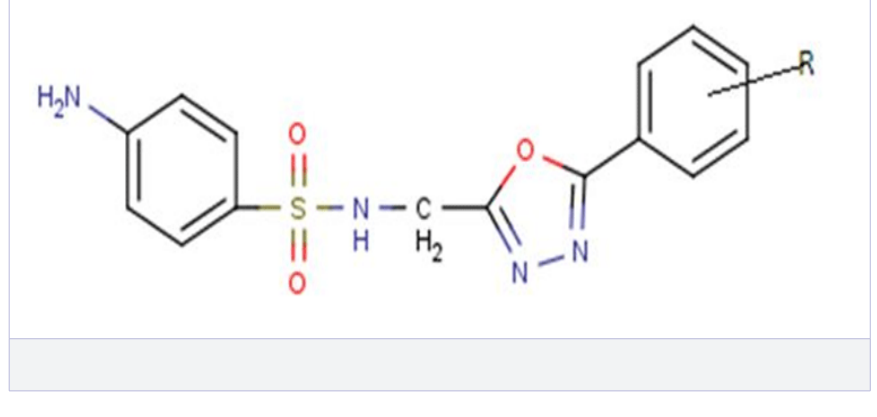

Table 1: Design of 1, 3, 4-oxadiazolyl sulphonamides

\begin{tabular}{|c|c|}
\hline Compound & $\mathbf{R}$ \\
\hline 1. & $\mathrm{H}$ \\
\hline 2. & $4-\mathrm{OH}$ \\
\hline 3. & $4-\mathrm{Cl}$ \\
\hline 4. & $4-\mathrm{NH}_{2}$ \\
\hline 5. & $4-\mathrm{OH}, 3-\mathrm{CH}_{3}$ \\
\hline 6. & $4-\mathrm{CH}\left(\mathrm{CH}_{3}\right)_{2}$ \\
\hline 7. & $4-\mathrm{C}\left(\mathrm{CH}_{3}\right)_{3}$ \\
\hline 8. & $4-\mathrm{N}_{3}\left(\mathrm{CH}_{3) 2}\right.$ \\
\hline 9. & $4-\mathrm{NO}_{2}$ \\
\hline 10. & $3,4,5-\left(\mathrm{OCH}_{3}\right)_{3}$ \\
\hline
\end{tabular}


Table 2: Nomenclature of the designed 1,3,4-oxadiazolyl sulphonamides using Chemicalize.org

\begin{tabular}{|c|c|c|}
\hline S.No & $\mathrm{R}$ & Nomenclature \\
\hline 1 & $\mathrm{H}$ & $\begin{array}{l}\text { IUPAC: 4-Amino-N-[(5-Phenyl-1,3,4-Oxadiazol-2-L)Methyl]Benzene-1-Sulfonamide } \\
\text { SMILES: INCHI: 1S/C15H14N403S/C16-12-6-8-13(9-7-12)23(20,21)17-10-14-18-19-15(22-14)11-4-2-1-3-5-11/H1- } \\
\text { 9,17H,10,16H2 } \\
\text { INCHI KEY: WOJFXQNTVVDWNV-UHFFFAOYSA-N }\end{array}$ \\
\hline 2 & $4-\mathrm{OH}$ & $\begin{array}{l}\text { IUPAC: 4-Amino-N-\{[5-(4-Hydroxyphenyl)-1,3,4-Oxadiazol-2-Yl]Methyl }\} \text { Benzene-1-Sulfonamide } \\
\text { SMILES: NC1=CC=C(C=C1)S(=0)(=0)NCC1=NN=C(01)C1=CC=C(O)C=C1 } \\
\text { INCHI: } 1 \mathrm{~S} / \mathrm{C} 15 \mathrm{H} 14 \mathrm{~N} 404 \mathrm{~S} / \mathrm{C} 16-11-3-7-13(8-4-11) 24(21,22) 17-9-14-18-19-15(23-14) 10-1-5-12(20) 6-2-10 / \mathrm{H} 1- \\
\text { 8,17,20H,9,16H2 } \\
\text { INCHI KEY: KVWVQFHGSYNLSC-UHFFFAOYSA-N } \\
\text { IUPAC: 4-Amino-N-\{[5-(4-Chlorophenyl)-1,3,4-Oxadiazol-2-Yl]Methyl }\} \text { Benzene-1-Sulfonamide }\end{array}$ \\
\hline 3 & $4-\mathrm{Cl}$ & $\begin{array}{l}\text { SMILES: NC1=CC=C(C=C1)S(=0)(=0)NCC1=NN=C(01)C1=CC=C(CL)C=C1 } \\
\text { INCHI: 1S/C15H13CLN4O3S/C16-11-3-1-10(2-4-11)15-20-19-14(23-15)9-18-24(21,22)13-7-5-12(17)6-8-13/H1- } \\
\text { 8,18H,9,17H2 } \\
\text { INCHI KEY: PPQSXSJNGVRRFB-UHFFFAOYSA-N }\end{array}$ \\
\hline 4 & $4-\mathrm{NH}_{2}$ & $\begin{array}{l}\text { IUPAC: } 4-A m i n o-N-\{[5-(4-A m i n o p h e n y l)-1,3,4-0 x a d i a z o l-2-Y l] M e t h y l\} B e n z e n e-1-S u l f o n a m i d e \\
\text { SMILES: NC1=CC=C(C=C1)C1=NN=C(CNS }=0)(=0) C 2=C C=C(N) C=C 2) O 1 \\
\text { INCHI: } 1 \text { S/C15H15N5O3S/C16-11-3-1-10(2-4-11)15-20-19-14(23-15)9-18-24(21,22)13-7-5-12(17)6-8-13/H1- } \\
\text { 8,18H,9,16-17H2 } \\
\text { INCHI KEY: CFKKLKAYSDHLBZ-UHFFFAOYSA-N }\end{array}$ \\
\hline 5 & $\begin{array}{l}\text { 4-OH, } \\
3-\mathrm{OCH}_{3}\end{array}$ & $\begin{array}{l}\text { IUPAC: 4-Amino-N-\{[5-(4-Hydroxy-3-Methoxyphenyl)-1,3,4-Oxadiazol-2-Yl]Methyl }\} \text { Benzene-1-Sulfonamide } \\
\text { SMILES: COC1=C(O)C=CC(=C1)C1=NN=C(CNS }(=0)(=0) C 2=C C=C(N) C=C 2) O 1 \\
\text { INCHI: } 1 \text { S/C16H16N4O5S/C1-24-14-8-10(2-7-13(14)21)16-20-19-15(25-16)9-18-26(22,23)12-5-3-11(17)4-6-12/ } \\
\text { H2-8,18,21H,9,17H2,1H3 } \\
\text { INCHI KEY: DQYQKXMOKGSEGM-UHFFFAOYSA-N }\end{array}$ \\
\hline 6 & $4-\mathrm{CH}\left(\mathrm{CH}_{3}\right)_{2}$ & $\begin{array}{l}\text { IUPAC: 4-Amino-N-(\{5-[4-(Propan-2-Yl)Phenyl]-1,3,4-Oxadiazol-2-Yl\}Methyl)Benzene-1-Sulfonamide } \\
\text { SMILES: CC(C)C1=CC=C(C=C1)C1=NN=C(CNS }(=0)(=0) C 2=C C=C(N) C=C 2) O 1 \\
\text { INCHI: } 1 \text { S/C18H20N4O3S/C1-12(2)13-3-5-14(6-4-13)18-22-21-17(25-18)11-20-26(23,24)16-9-7-15(19)8-10-16/ } \\
\text { H3-10,12,20H,11,19H2,1-2H3 } \\
\text { INCHI KEY: XALHGEIOZWCCHJ-UHFFFAOYSA-N }\end{array}$ \\
\hline 7 & $4-\mathrm{C}\left(\mathrm{CH}_{3}\right)_{3}$ & $\begin{array}{l}\text { IUPAC: 4-Amino-N- }\{[5-(4-T e r t-B u t y l p h e n y l)-1,3,4-0 x a d i a z o l-2-Y l] M e t h y l\} \text { Benzene-1-Sulfonamide } \\
\text { SMILES: } C C(C)(C) C 1=C C=C(C=C 1) C 1=N N=C(C N S(=0)(=0) C 2=C C=C(N) C=C 2) 01 \\
\text { INCHI: } 1 S / C 19 H 22 N 403 S / C 1-19(2,3) 14-6-4-13(5-7-14) 18-23-22-17(26-18) 12-21-27(24,25) 16-10-8-15(20) 9-11- \\
\text { 16/H4-11,21H,12,20H2,1-3H3 } \\
\text { INCHI KEY: QVTZXCYLTOXWHY-UHFFFAOYSA-N }\end{array}$ \\
\hline 8 & $4-\mathrm{N}\left(\mathrm{CH}_{3}\right)_{2}$ & 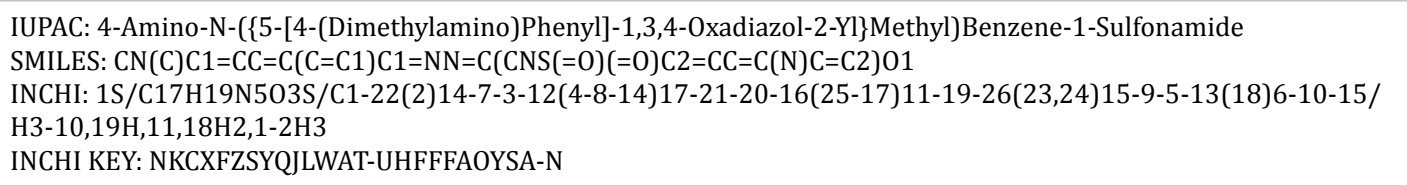 \\
\hline 9 & $4-\mathrm{NO}_{2}$ & 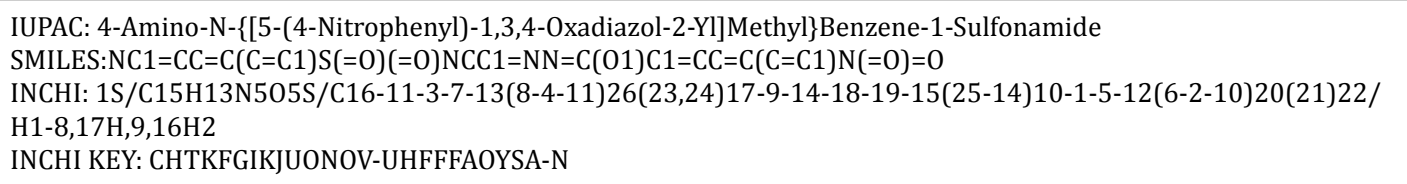 \\
\hline 10 & $3,4,5-\left(\mathrm{OCH}_{3}\right)_{3}$ & 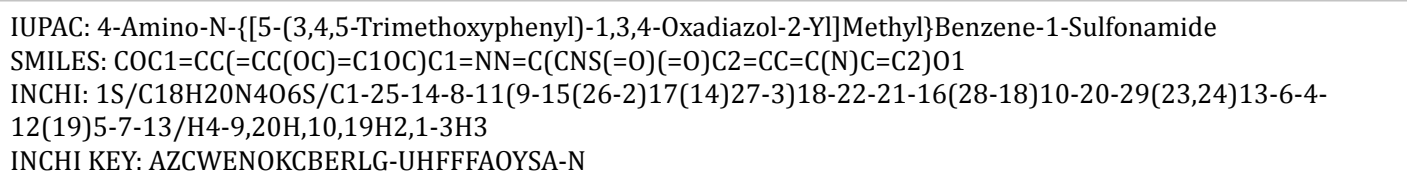 \\
\hline
\end{tabular}




\section{Molecular properties predictions}

Lipinski's Rule of Five describes molecular properties important for a drug's pharmacokinetics in the human body, including their absorption, distribution, metabolism, and excretion [20]. Using Chemicalize, molinspiration and molsoft, molecular properties were predicted for the designed compounds. The results obtained revealed that all the compounds tested obeyed Lipinski rule of five with not more than 5 hydrogen bond donors ( $\mathrm{OH}$ and $\mathrm{NH}$ groups), not more than 10 hydrogen bond acceptors (notably $\mathrm{N}$ and 0 ), not more than 15 rotatable bonds (rotb), molecular weight under $500 \mathrm{~g} / \mathrm{mol}$ and a partition coefficient, log P less than 5 except for compound $3 \& 8$ (Tables 3-6). All the compounds tested also passed the other Lipinski like filter such as bioavailability.
Absorption is defined as the process involved in getting a drug from its dosage form into the body and the ability to predict the percent oral absorption is primary goal in the design, optimization, and selection of potential candidates in the development of oral drugs. Topological Polar surface area (TPSA) is another key property that has been linked to bioavailability and it was found that passively absorbed molecules with a TPSA more than 140 are thought to have low oral availability [21]. TPSA obtained for the tested compounds were below 140 indicating their good oral bioavailability. Thus these results predicted the good drug likeliness, solubility, permeability and oral bioavailability of compounds. No compound violated the Lipinski rule of five (Table 3, Table 4, Table 5, Table 6).

Table 3: Molecular properties prediction of title compounds using Chemicalize.org

\begin{tabular}{|c|c|c|c|c|c|c|}
\hline S.NO & $\mathrm{R}$ & Molecular Formula & $\begin{array}{c}\text { Molecular } \\
\text { weight }\end{array}$ & Log P & TPSA & SASA \\
\hline 1 & $\mathrm{H}$ & $\mathrm{C}_{15} \mathrm{H}_{14} \mathrm{~N}_{4} \mathrm{O}_{3} \mathrm{~S}$ & 330.362 & 0.78 & 111.11 & 436.55 \\
\hline 2 & $4-\mathrm{OH}$ & $\mathrm{C}_{15} \mathrm{H}_{14} \mathrm{~N}_{4} \mathrm{O}_{4} \mathrm{~S}$ & 346.361 & 0.47 & 131.34 & 447.81 \\
\hline 3 & $4-\mathrm{Cl}$ & $\mathrm{C}_{15} \mathrm{H}_{13} \mathrm{ClN}_{4} \mathrm{O}_{3} \mathrm{~S}$ & 364.807 & 1.38 & 111.11 & 452.77 \\
\hline 4 & $4-\mathrm{NH}_{2}$ & $\mathrm{C}_{15} \mathrm{H}_{5} \mathrm{~N}_{5} \mathrm{O}_{3} \mathrm{~S}$ & 345.376 & -0.05 & 137.13 & 451.37 \\
\hline 5 & $4-\mathrm{OH}, 3-\mathrm{OCH}_{3}$ & $\mathrm{C}_{16} \mathrm{H}_{16} \mathrm{~N}_{4} \mathrm{O}_{5} \mathrm{~S}$ & 76.387 & 0.32 & 140.57 & 495.57 \\
\hline 6 & $4-\mathrm{CH}\left(\mathrm{CH}_{3}\right)_{2}$ & $\mathrm{C}_{25} \mathrm{H}_{23} \mathrm{~N}_{3} \mathrm{O}_{5}$ & 372.441 & 2.02 & 111.11 & 528.98 \\
\hline 7 & $4-\mathrm{C}\left(\mathrm{CH}_{3}\right)_{3}$ & $\mathrm{C}_{26} \mathrm{H}_{25} \mathrm{~N}_{3} \mathrm{O}_{5}$ & 386.468 & 2.32 & 111.11 & 564.79 \\
\hline 8 & $4-\mathrm{N}_{\left(-\mathrm{CH}_{3}\right)_{2}}$ & $\mathrm{C}_{16} \mathrm{H}_{16} \mathrm{~N}_{4} \mathrm{O}_{5} \mathrm{~S}$ & 376.387 & 0.32 & 140.57 & 495.57 \\
\hline 9 & $4-\mathrm{NO}_{2}$ & $\mathrm{C}_{15} \mathrm{H}_{13} \mathrm{~N}_{5} \mathrm{O}_{5} \mathrm{~S}$ & 375.359 & 0.72 & 156.93 & 476.76 \\
\hline 10 & $3,4,5-\left(\mathrm{OCH}_{3) 3}\right.$ & $\mathrm{C}_{18} \mathrm{H}_{20} \mathrm{~N}_{4} \mathrm{O}_{6} \mathrm{~S}$ & 420.44 & 0.3 & 138.8 & 580.24 \\
\hline
\end{tabular}

Log P- Partition co efficient

TPSA - Topological Polar surface area

SASA- Solvent Accessible Surface Area

Table 4: Molecular properties prediction of title compounds using Chemicalize.org

\begin{tabular}{|c|c|c|c|c|c|c|c|}
\hline S.NO & R & Lipinski rule of five & $\begin{array}{c}\text { Bio- } \\
\text { availability }\end{array}$ & $\begin{array}{c}\text { Ghose } \\
\text { filter }\end{array}$ & $\begin{array}{c}\text { Lead likeness } \\
\text { Mugge } \\
\text { Filter }\end{array}$ & $\begin{array}{c}\text { Veber } \\
\text { filter }\end{array}$ \\
\hline 1 & $\mathrm{H}$ & Yes & Yes & Yes & Yes & Yes \\
\hline 2 & $4-\mathrm{OH}$ & Yes & Yes & Yes & No & Yes \\
\hline 3 & $4-\mathrm{Cl}$ & Yes & Yes & Yes & Yes & Yes \\
\hline 4 & $4-\mathrm{NH}_{2}$ & Yes & Yes & Yes & Yes & Yes \\
\hline 5 & $4-\mathrm{OH}, 3-\mathrm{OCH}_{3}$ & Yes & Yes & Yes & Yes & Yes \\
\hline 6 & $4-\mathrm{CH}\left(\mathrm{CH}_{3}\right)_{2}$ & Yes & Yes & Yes & Yes & Yes \\
\hline 7 & $4-\mathrm{C}\left(\mathrm{CH}_{3}\right)_{3}$ & Yes & Yes & Yes \\
\hline 8 & $4-\mathrm{N}_{2}\left(\mathrm{CH}_{3}\right)_{2}$ & Yes & Yes & Yes & Yes & Yes \\
\hline 9 & $4-\mathrm{NO}_{2}$ & Yes & Yes & Yes & Yes & No \\
\hline 10 & $3,4,5-\left(\mathrm{OCH}_{3}\right)_{3}$ & Yes & Yes & Yes & Yes & Yes \\
\hline
\end{tabular}


An approach to design, In silico predictions and molecular docking studies of 1,3,4-oxadiazolyl sulphonamides as possible inhibitors of bacterial Mur enzymes, the amino acid ligases in

Table 5: Molecular properties prediction of title compounds using molinspiration.com

\begin{tabular}{|c|c|c|c|c|c|c|c|c|c|}
\hline S.No & $\mathrm{R}$ & $\mathrm{nON}$ & nOHNH & N violations & nrotob & Volume & Mi Logp & n Atoms \\
\hline 1 & $\mathrm{H}$ & 7 & 3 & 0 & 5 & 272.04 & 0.903 & 23 \\
\hline 2 & $4-\mathrm{OH}$ & 8 & 4 & 0 & 5 & 280.058 & 0.424 & 24 \\
\hline 3 & $4-\mathrm{Cl}$ & 7 & 3 & 0 & 5 & 285.576 & 1.581 & 24 \\
\hline 4 & $4-\mathrm{NH}_{2}$ & 8 & 5 & 0 & 5 & 283.329 & 0.021 & 24 \\
\hline 5 & $4-\mathrm{OH}, 3-\mathrm{OCH}_{3}$ & 9 & 4 & 0 & 6 & 305.604 & 0.243 & 26 \\
\hline 6 & $4-\mathrm{CH}\left(\mathrm{CH}_{3}\right)_{2}$ & 7 & 3 & 0 & 6 & 321.99 & 2.416 & 26 \\
\hline 7 & $4-\mathrm{C}\left(\mathrm{CH}_{3}\right)_{3}$ & 7 & 3 & 0 & 6 & 338.227 & 2.61 & 27 \\
\hline 8 & $4-\mathrm{N}_{2}\left(\mathrm{CH}_{3) 2}\right.$ & 8 & 3 & 0 & 6 & 317.946 & 1.006 & 26 \\
\hline 9 & $4-\mathrm{NO}_{2}$ & 10 & 3 & 0 & 6 & 295.374 & 0.862 & 26 \\
\hline 10 & $3,4,5-\left(\mathrm{OCH}_{3}\right)_{3}$ & 10 & 3 & 0 & 8 & 348.677 & 0.535 & 29 \\
\hline
\end{tabular}

Table 6: Molecular properties prediction of title compounds using molsoft.com

\begin{tabular}{|c|c|c|c|c|c|c|c|c|}
\hline S.No & $\mathrm{R}$ & No of HBA & No of HBD & Mol Log $p$ & Mol Log s & Mol PSA (A2) & $\begin{array}{l}\text { Mol volume } \\
\text { (A3) }\end{array}$ & $\begin{array}{l}\text { No of stereo } \\
\text { centres }\end{array}$ \\
\hline 1 & $\mathrm{H}$ & 6 & 3 & 1.7 & $\begin{array}{l}\text {-3.71(in Log(moles/L) } 64.84 \\
\text { (in mg/L) }\end{array}$ & 92.98 A2 & 274.16 A3 & 0 \\
\hline 2 & $4-\mathrm{OH}$ & 7 & 4 & 1.44 & $\begin{array}{l}\text {-3.56(in Log(moles/L) } 94.63 \\
\text { (in mg/L) }\end{array}$ & $110.60 \mathrm{~A} 2$ & $284.70 \mathrm{~A} 3$ & 0 \\
\hline 3 & $4-\mathrm{Cl}$ & 6 & 3 & 1.6 & $\begin{array}{l}\text {-3.86(in Log(moles/L)94.63 } \\
\text { (in mg/L) }\end{array}$ & $111.06 \mathrm{~A} 2$ & 264.16 A3 & 0 \\
\hline 4 & $4-\mathrm{NH}_{2}$ & 6 & 5 & 1.2 & $\begin{array}{l}-3.88(\mathrm{inLog}(\mathrm{moles} / \mathrm{L})) \\
45.80(\mathrm{in} \mathrm{mg} / \mathrm{L})\end{array}$ & $113.79 \mathrm{~A} 2$ & 281.58 A3 & 0 \\
\hline 5 & $4-\mathrm{OH}, 3-\mathrm{OCH}_{3}$ & 8 & 4 & 1.4 & $\begin{array}{l}-3.83(\mathrm{inLog}(\mathrm{moles} / \mathrm{L})) \\
55.73(\mathrm{in} \mathrm{mg} / \mathrm{L})\end{array}$ & $117.16 \mathrm{~A} 2$ & 317.35 A3 & 0 \\
\hline 6 & $4-\mathrm{CH}\left(\mathrm{CH}_{3}\right)_{2}$ & 6 & 3 & 2.82 & $\begin{array}{l}\text {-5.18(inLog(moles/L)) } 2.43 \\
\text { (in mg/L) }\end{array}$ & 92.98 A2 & 327.14 A3 & 0 \\
\hline 7 & $4-\mathrm{C}\left(\mathrm{CH}_{3}\right)_{3}$ & 6 & 3 & 3.31 & $\begin{array}{l}\text {-5.84(inLog(moles/L)) } 0.56 \\
\text { (in mg/L) }\end{array}$ & 92.98 A2 & 358.69 A3 & 0 \\
\hline 8 & $4-\mathrm{N}\left(\mathrm{CH}_{3}\right)_{2}$ & 6 & 3 & 1.82 & $\begin{array}{l}-4.28(\mathrm{inLog}(\mathrm{moles} / \mathrm{L})) \\
19.73 \text { (in mg/L) }\end{array}$ & 95.79 A2 & 323.64 A3 & 0 \\
\hline 9 & $4-\mathrm{NO}_{2}$ & 8 & 3 & 1.37 & $\begin{array}{l}-4.80(\text { inLog(moles/L)) } 6.00 \\
\text { (in mg/L) }\end{array}$ & 126.37 A2 & 299.07 A3 & 0 \\
\hline 10 & $3,4,5-\left(\mathrm{OCH}_{3}\right)_{3}$ & 9 & 3 & 1.73 & $\begin{array}{l}-3.87(\text { inLog(moles/L)) } \\
56.23 \text { (in mg/L) }\end{array}$ & $115.96 \mathrm{~A} 2$ & 369.19 A3 & 0 \\
\hline
\end{tabular}

\section{Druglikeness and bioactivity scores}

Prediction of bioactivity score for the most important drug targets (GPCR ligands, kinase inhibitors, ion channel modulators, nuclear receptors. Drug likeness may be defined as a complex balance of various molecular properties and structure features which determine whether particular molecule is similar to the known drugs. Table 7 and 8 lists the predicted values of selected parameters for compounds. Positive scores were obtained for the compounds indicating the potential quinazolinone nucleus and amino acid residues. The presence of the two pharmacophoric scaffolds, oxadiazole and sulphonamide influenced the good bioactive scores. Compounds 6 \& 7 with electron donating substituents showed positive scores as protease inhibitor and enzyme inhibitors. The compounds showed positive drug likeness scores which is a good indication of being active compounds. Among the compounds $6 \& 7$ were found to be potent with good druglikeness scores nearer to 1 (Table 7, Table 8). 
An approach to design, In silico predictions and molecular docking studies of 1,3,4-oxadiazolyl sulphonamides as possible inhibitors of bacterial Mur enzymes, the amino acid ligases in

Table 7: Bioactivity prediction of title compounds using molinspiration.com

\begin{tabular}{|c|c|c|c|c|c|c|c|}
\hline S.No & $\mathrm{R}$ & GPCR Ligand & Ion Channel Modulator & Kinase Inhibitor & Nuclear Receptor Ligand & $\begin{array}{c}\text { Protease } \\
\text { Inhibitor }\end{array}$ & $\begin{array}{c}\text { Enzyme } \\
\text { Inhibitor }\end{array}$ \\
\hline 1 & $\mathrm{H}$ & -0.18 & -0.4 & -0.12 & -0.58 & 0.06 & -0.07 \\
\hline 2 & $4-\mathrm{OH}$ & -0.13 & -0.34 & -0.08 & -0.4 & 0.09 & -0.02 \\
\hline 3 & $4-\mathrm{Cl}$ & -0.17 & -0.39 & -0.14 & -0.57 & 0.03 & -0.11 \\
\hline 4 & $4-\mathrm{NH}_{2}$ & -0.17 & -0.38 & -0.12 & -0.54 & 0.07 & -0.07 \\
\hline 5 & $4-\mathrm{OH}, 3-\mathrm{OCH}_{3}$ & -0.18 & -0.39 & -0.07 & -0.47 & -0.02 & -0.05 \\
\hline 6 & $4-\mathrm{CH}\left(\mathrm{CH}_{3}\right)_{2}$ & -0.16 & -0.37 & -0.17 & -0.45 & 0.07 & 0.07 \\
\hline 7 & $4-\mathrm{C}\left(\mathrm{CH}_{3}\right)_{3}$ & -0.12 & -0.29 & -0.12 & -0.38 & 0.07 & 0.06 \\
\hline 8 & $\left.4-\mathrm{N}_{2} \mathrm{CH}_{3}\right)_{2}$ & -0.15 & -0.37 & -0.09 & -0.48 & -0.06 & -0.08 \\
\hline 9 & $4-\mathrm{NO}_{2}$ & -0.3 & -0.4 & -0.26 & -0.6 & -0.06 \\
\hline 10 & $3,4,5-\left(\mathrm{OCH}_{3}\right)_{3}$ & -0.21 & -0.4 & -0.11 & -0.56 & -0.17 \\
\hline
\end{tabular}

Table 8: Druglikeness score prediction of title compounds using Molsoft.com

\begin{tabular}{|c|c|c|}
\hline S.No & $\mathrm{R}$ & Druglikeness score \\
\hline 1 & $\mathrm{H}$ & 0.41 \\
\hline 2 & $4-\mathrm{OH}$ & 0.24 \\
\hline 3 & $4-\mathrm{Cl}$ & 0.33 \\
\hline 4 & $4-\mathrm{NH}_{2}$ & 0.50 \\
\hline 5 & $4-\mathrm{OH}, 3-\mathrm{OCH}_{3}$ & 0.74 \\
\hline 6 & $4-\mathrm{CH}\left(\mathrm{CH}_{3}\right)_{2}$ & 0.93 \\
\hline 7 & $4-\mathrm{C}\left(\mathrm{CH}_{3}\right)_{3}$ & 0.83 \\
\hline 8 & $4-\mathrm{N}\left(\mathrm{CH}_{3}\right)_{2}$ & 0.48 \\
\hline 9 & $4-\mathrm{NO}_{2}$ & 0.36 \\
\hline 10 & $3,4,5-\left(\mathrm{OCH}_{3}\right)_{3}$ & 0.74 \\
\hline
\end{tabular}

\section{Docking studies:}

The virtual screening of drug like molecules against a protein target is a common strategy used to identify novel inhibitors. The designed compounds exhibited good binding interactions with Mur enzymes, specifically with x-ray crystallographic structures of UDP-N[Mur A]PDB ID:1a2n, UDP-N[Mur C]PDB ID:1GQ7, UDP-N [Mur E] PDB ID:2XJA. MurA is the only cytoplasmic step inhibited by a clinically used antibacterial agent. Fosfomycin, a naturally occurring broad spectrum antibiotic, is the best known inhibitor of MurA. [22]. It has been the drug of choice for the treatment of paediatric gastrointestinal infections resulting from Shiga-like toxin-producing Escherichia coli (STEC). It is also among the firstline agents for the treatment of bacterial infections of the urinary tract, which is a common health problem, particularly in women [23]. Inhibition of MurA enzyme by fosfomycin is competitive, the antibiotic acting as an analogue of PEP and forming a covalent bond with the active cysteine residue of the enzyme (Figure 3).<smiles>CC(C)c1ccc(-c2nnc(CNS(=O)(=O)c3ccc(N)cc3)o2)cc1</smiles><smiles>CC(C)(C)c1ccc(-c2nnc(CNS(=O)(=O)c3ccc(N)cc3)o2)cc1</smiles><smiles>Nc1ccc(S(=O)(=O)NCc2nnc(-c3ccc([N+](=O)[O-])cc3)o2)cc1</smiles>

compound 9

Figure 3: Title compounds selected for docking studies 
Mur C enzyme catalyzes the stepwise formation of the peptide moiety of the peptidoglycan disaccharide peptide monomer unit. MurC is responsible of the addition of the first residue (L-alanine) onto the nucleotide precursor UDP-MurNAc. The first phosphinate inhibitor of MurE was designed with structural features based on Tanner's previously reported MurD phosphinate inhibitor [23]. Several analogues of diaminopimelic acid were also tested as substrates or inhibitors of MurE [22].

Table 9 indicates the docking scores, binding energies and compared with the standard. All the compounds exhibited good binding energies, of which the propyl and t-butyl substituted phenyl ring containing compounds showed stronger interactions.
The detailed interaction of active compounds with Mur A, Mur $\mathrm{C}$ and Mur E are given in tables 10,11 and 12 respectively. Most of the interactions of the compounds with amino acids at active site of the enzymes were due to hydrogen bonds, van der Waals and hydrophobic attractions. Compounds $6[\Delta \mathrm{G}=-9.8(\mathrm{Kcal} / \mathrm{mol})]$ and compound $9[\Delta \mathrm{G}=-9.5(\mathrm{Kcal} / \mathrm{mol})]$ were found to have good interactions at active site of Mur A enzyme than the standard Mur A inhibitor, Fosfomycin $[\Delta \mathrm{G}=-4.8(\mathrm{Kcal} / \mathrm{mol})]$ (Figure 4$)$. The nitro group increased its efficiency or conformation of compounds towards active interaction. Schonbrunn et al reported similar type of interaction of the fluorescence probe 8-anilino-1-naphthalene sulfonate (ANS) with the antibiotic target MurA [25].
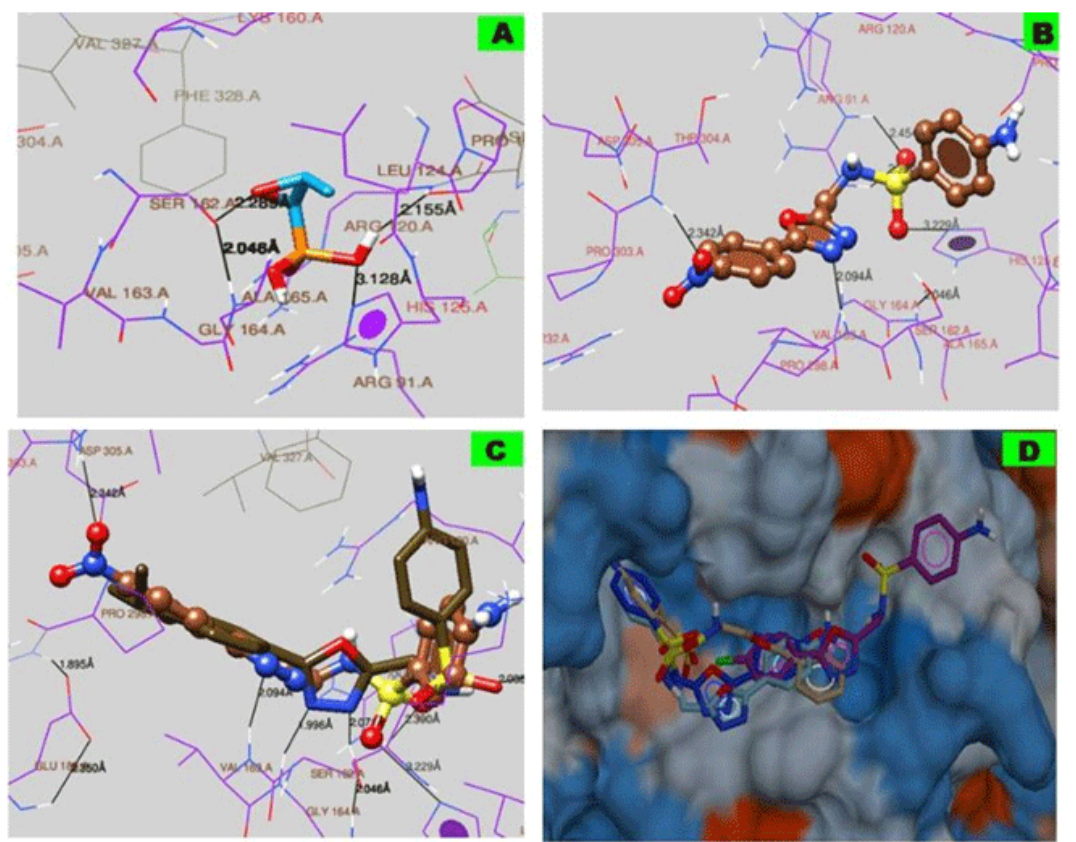

Figure 4: Hypothetical binding interactions of selected compounds and hydrogen bonds as black lines with bond length in the UDP-N [Mur A] (PDB ID:1a2n) active site with amino acids(wire model) (a) Compound Fosfomycin (blue colored stick model) Carbon(light blue), Sulfur(yellow), Oxygen(red), Nitrogen(blue) and Hydrogen (white) (b) compound 9 (light brown colored ball and stick model) Carbon(light brown), Sulfur(yellow), Oxygen(red), Nitrogen(blue) and Hydrogen (white) (c) Superimposition of compounds at the active site.(d) superimposition of the compounds in hydrophobic pocket Carbon(light blue, light brown), Sulfur(yellow), Oxygen(red), Nitrogen(blue) and Hydrogen (white)

Compound $6[\Delta \mathrm{G}=-9.7(\mathrm{Kcal} / \mathrm{mol})]$ and compound $7[\Delta \mathrm{G}=$ $-9.6(\mathrm{Kcal} / \mathrm{mol})]$ were found to have good interactions at active site of Mur C enzyme than the standard Mur C inhibitor, Diamino pimilic acid Phosphinate $[\Delta \mathrm{G}=-5.2(\mathrm{Kcal} / \mathrm{mol})]$ (Figure 5). The active site contains amino acids as reported by Spraggon et al and the compounds exhibited strong interactions [25]. Compounds $6[\Delta \mathrm{G}=-9.8(\mathrm{Kcal} / \mathrm{mol})]$ and compound $7[\Delta \mathrm{G}=-9.7(\mathrm{Kcal} / \mathrm{mol})]$ were found to have good interactions at active site of Mur E enzyme than the standard Mur E inhibitor, Diamino pimilic acid Phosphinate $[\Delta \mathrm{G}=-5.2(\mathrm{Kcal} / \mathrm{mol})]$ (Figure 6).

Of all the compounds, compound $\mathbf{6}$ and compound $\mathbf{9}$ with isopropyl substitution exhibited the highest scores against all the three Mur enzymes. Compound 7 showed good binding interactions with Mur C and Mur E. The Mur E enzyme of Mur pathway of Mycobacterium tuberculosis is an attractive drug target as it is unique to bacteria and is absent in mammalian cells [26].

This indicates the high specificity and good interactions of the compounds at binding pockets of these Mur enzymes. Docking studies were also conducted on Alpha amylase PDB ID: 3BC9 and Dihydropteroate synthase PDB ID:1ad4, but the compounds exhibited only mild interactions. Thus the compounds were found to be selective towards Mur enzymes (Table 9, Table 10, Table11, Table 12) (Figure 4, Figure 5, Figure 6). 

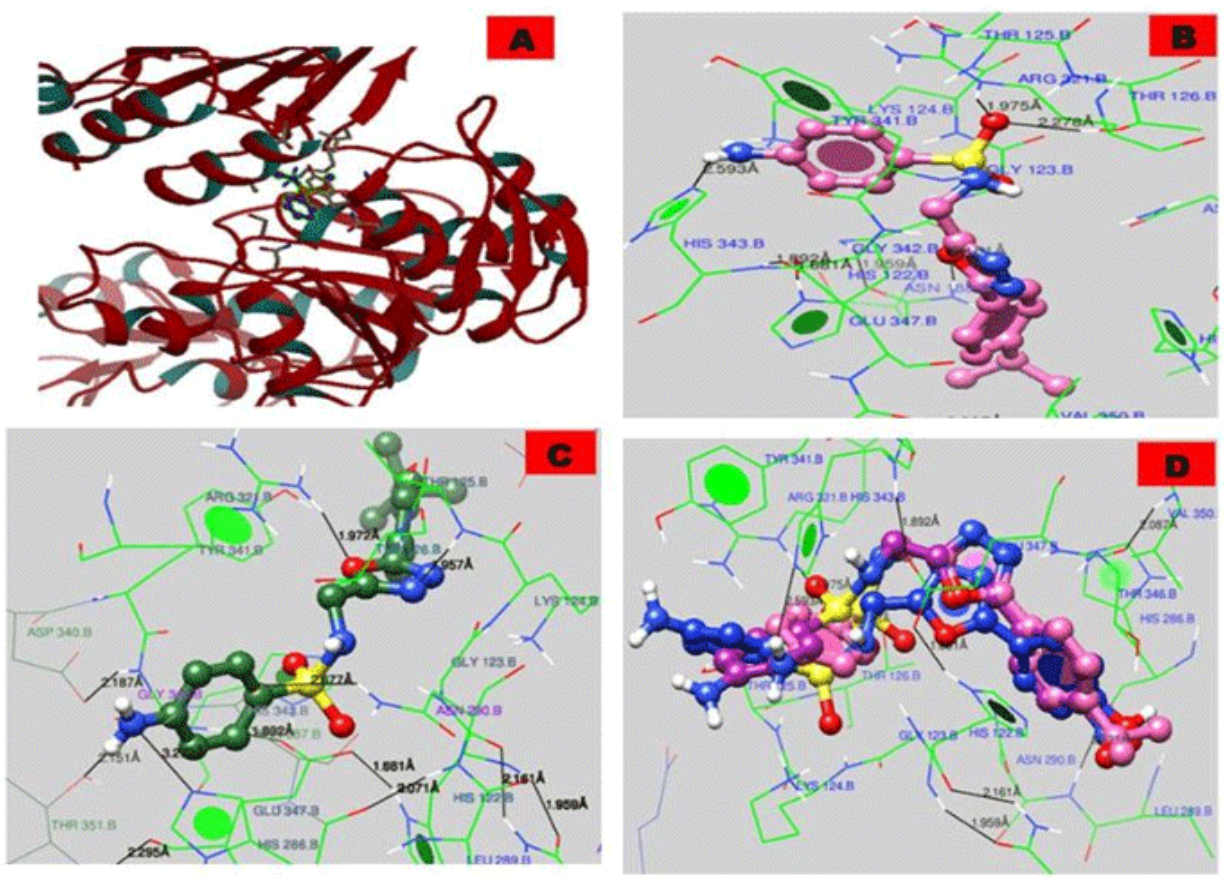

Figure 5: Hypothetical binding interactions of selected compounds and hydrogen bonds as black lines with bond length in the UDP-N[Mur C](PDB ID:1GQ7 ) active site with amino acids(wire model) (a) Compound phosphinate (violet colored ball and stick model) Carbon(violet), Sulfur(yellow), Oxygen(red), Nitrogen(blue) and Hydrogen (white) (b) compound 6 (light pink colored ball and stick model) Carbon(light pink), Sulfur(yellow), Oxygen(red), Nitrogen(blue) and Hydrogen (white) (c) compound 7 (green colored ball and stick model) (d) superimposition of the compounds in hydrophobic pocket,Carbon(violet, light pink), Sulfur(yellow), Oxygen(red), Nitrogen(blue) and Hydrogen (white)

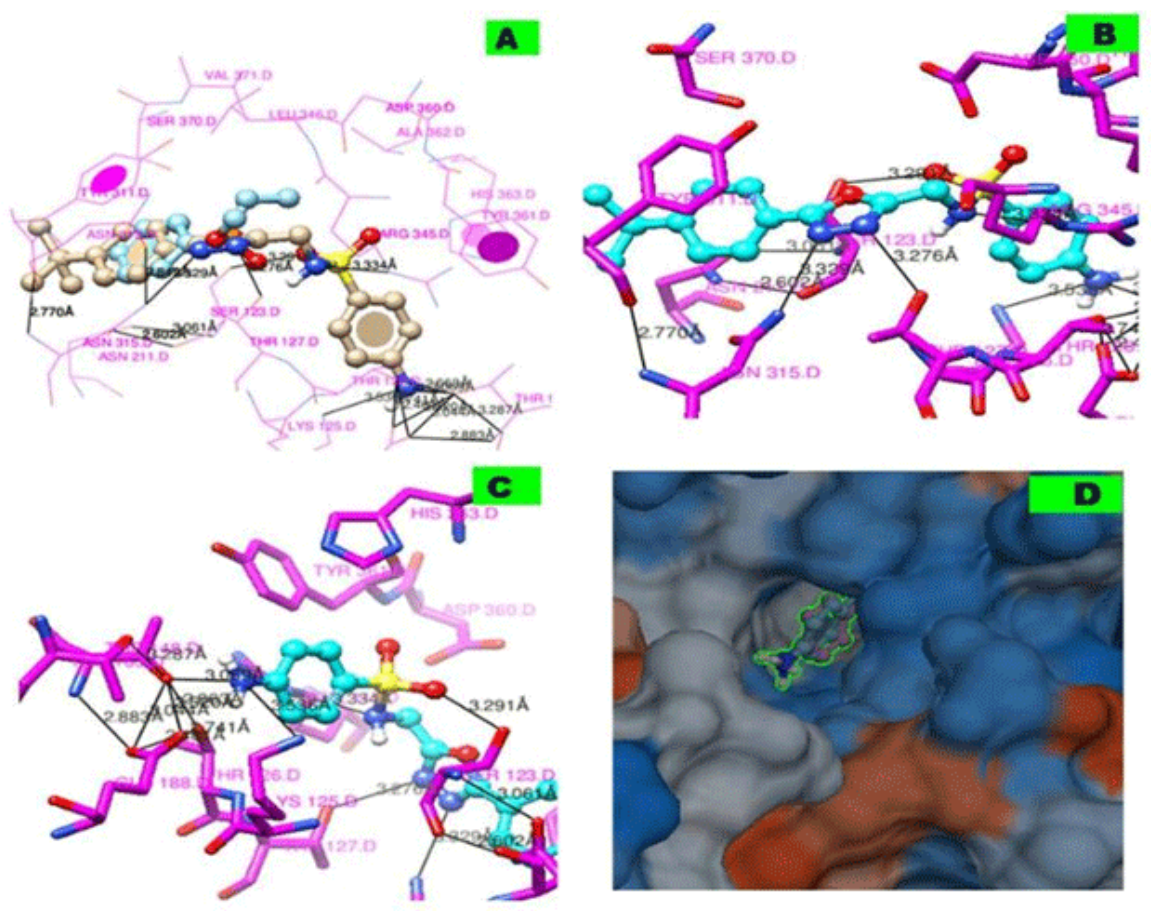

Figure 6: Hypothetical binding interactions of selected compounds and hydrogen bonds as black lines with bond length in the UDP-N[Mur E]PDB ID:2XJA active site with amino acids(wire model) (a) compound 7 (silver colored ball and stick model) and phosphinate(light blue colored ball and stick model) Carbon(silver), Sulfur(yellow), Oxygen(red), Nitrogen(blue) and Hydrogen (white) (b) and (c) compound 6 (cyan colored ball and stick model) Carbon(cyan), Sulfur(yellow), Oxygen(red), Nitrogen(blue) and Hydrogen (white) (d) superimposition of the compounds in hydrophobic pocket Carbon(silver, cyan), Sulfur(yellow), Oxygen(red), Nitrogen(blue) and Hydrogen (white) 
An approach to design, In silico predictions and molecular docking studies of 1,3,4-oxadiazolyl sulphonamides as possible inhibitors of bacterial Mur enzymes, the amino acid ligases in

\begin{tabular}{|c|c|c|c|c|c|c|}
\hline \multirow[t]{2}{*}{ S.No } & \multirow[t]{2}{*}{$\mathrm{R}$} & \multicolumn{5}{|c|}{ Targets and Estimated binding energy $\Delta \mathrm{G}(\mathrm{Kcal} / \mathrm{mol})$ a } \\
\hline & & $\begin{array}{c}\text { UDP-N } \\
\text { [Mur A] } \\
\text { PDB ID:1a2n }\end{array}$ & $\begin{array}{c}\text { UDP-N } \\
\text { [Mur C] } \\
\text { PDB ID:1GQ7 }\end{array}$ & $\begin{array}{c}\text { UDP-N } \\
\text { [Mur E] } \\
\text { PDB ID:2XJA }\end{array}$ & $\begin{array}{c}\text { Alpha } \\
\text { amylase } \\
\text { PDB ID:3BC9 }\end{array}$ & $\begin{array}{c}\text { Dihydro } \\
\text { pteroate synthase } \\
\text { PDB ID:1ad4 }\end{array}$ \\
\hline 1 & $\mathrm{H}$ & -9 & -9.2 & -9.3 & -7.5 & -6.6 \\
\hline 2 & $4-\mathrm{OH}$ & -9.1 & -9.1 & -9.2 & -7.7 & -6.4 \\
\hline 3 & $4-\mathrm{Cl}$ & -9.3 & -9.1 & -8.3 & -7.5 & -6.9 \\
\hline 4 & $4-\mathrm{NH}_{2}$ & -9.2 & -9.1 & -8.2 & -7.6 & -6.8 \\
\hline 5 & $\begin{array}{l}\text { 4-OH, } \\
3-\mathrm{OCH}_{3}\end{array}$ & -9.1 & -9.1 & -9.3 & -7.5 & -7 \\
\hline 6 & $4-\mathrm{CH}\left(\mathrm{CH}_{3}\right)_{2}$ & -9.8 & -9.7 & -9.8 & -7.9 & -6.8 \\
\hline 7 & $4-\mathrm{C}\left(\mathrm{CH}_{3}\right)_{3}$ & -8.8 & -9.6 & -9.7 & -7.8 & -6.6 \\
\hline 8 & $4-\mathrm{N}\left(\mathrm{CH}_{3}\right)_{2}$ & -9 & -9 & -9.5 & -7.6 & -6.4 \\
\hline 9 & $4-\mathrm{NO}_{2}$ & -9.5 & -9.5 & -9.5 & -7.7 & -6.9 \\
\hline 10 & $3,4,5-\left(\mathrm{OCH}_{3}\right)_{3}$ & -8.7 & -9.1 & -8.3 & -7.3 & -6.8 \\
\hline 11 & Standard & $\begin{array}{c}-4.8 \\
\text { Fosfomycin }\end{array}$ & $\begin{array}{c}-5.2 \\
\text { Diamino pimilic acid } \\
\text { Phosphinate }\end{array}$ & $\begin{array}{c}-5.2 \\
\text { Diamino pimilic acid } \\
\text { Phosphinate }\end{array}$ & & $\begin{array}{l}\text { Sulfadiazine } \\
\quad-4.7\end{array}$ \\
\hline
\end{tabular}

Table 10: Binding interactions of active compounds with UDP-N[Mur A]PDB ID:1a2n (His-Histidine, Pro-Proline, Ser-Serine, Thr-Threonine, GlyGlycine, Val-Valine, Arg-Arginine, Leu-Leucine)

\begin{tabular}{|c|c|c|}
\hline Compound & Hydrogen bond interactions & Other interactions \\
\hline \multirow[t]{2}{*}{ Fosfomycin } & - $\quad$ Phosphate(OH)-His ${ }_{125 \mathrm{~A}}(\sim 3.128 \AA ̊)$ & van der Waals interactions of methyl group with $\mathrm{Leu}_{124 \mathrm{~A}}$ and $\operatorname{Arg}_{120 \mathrm{~A}}$ \\
\hline & 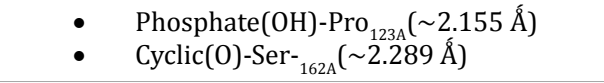 & \\
\hline Compound 6 & 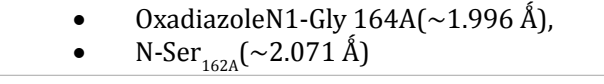 & $\begin{array}{l}\text { Hydrophobic aromatic pockets- }\left(\mathrm{His}_{125 \mathrm{~B}}, \mathrm{Pro}_{303 \mathrm{~A}^{\prime}}, \mathrm{Pro}_{293 \mathrm{~A}}\right) \\
\text { van der Waals interactions - }\left(\mathrm{Gly}_{164 \mathrm{~A}^{\prime}}, \mathrm{Val}_{163 \mathrm{~A}^{\prime}} \mathrm{Thr}_{304 \mathrm{~A}}\right)\end{array}$ \\
\hline Compound 9 & 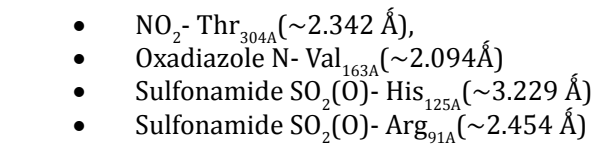 & $\begin{array}{l}\text { van der Waals interactions - }\left(\mathrm{Gly}_{164 A}, \mathrm{Val}_{163 \mathrm{~A}}, \mathrm{Thr}_{304 \mathrm{~A}}\right) \\
\left.\text { Hydrophobic aromatic pockets-( } \mathrm{His}_{125 \mathrm{~B}}, \mathrm{PrO}_{303 \mathrm{~A}}, \mathrm{PrO}_{293 \mathrm{~A}}\right)\end{array}$ \\
\hline
\end{tabular}

Table 11: Binding interactions of active compounds with UDP-N[Mur C]PDB ID:1GQ7(His-Histidine, Pro-Proline, Ser-Serine, Thr-Threonine, GlyGlycine, Val-Valine, Arg-Arginine, Lys-Lysine, Tyr-Tyrosine)

\begin{tabular}{|c|c|c|}
\hline Compound & Hydrogen bond interactions & Other interactions \\
\hline Phosphinate & - & $\begin{array}{l}\text { van der Waals interactions of methyl group with } \mathrm{Thr}_{120 \mathrm{~B}}, \mathrm{Gly}_{123 \mathrm{~B}^{\mathrm{B}}}, \mathrm{Gly}_{342} \mathrm{~B} \text { and } \\
\mathrm{Arg}_{321 \mathrm{~B}^{\prime}} \text {, Aromatic interactions with His } \\
2866 \mathrm{~B}\end{array}$ \\
\hline Compound 6 & 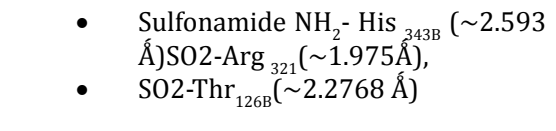 & $\begin{array}{l}\text { Hydrophobic aromatic pockets- }\left(\mathrm{Tyr}_{341 \mathrm{~B}}, \mathrm{His}_{122 \mathrm{~B}}, \mathrm{His}_{344 \mathrm{~B}}, \mathrm{His}_{286 \mathrm{~B}}\right) \\
\left.\text { Van der Waals interactions -( } \mathrm{Lys}_{124 \mathrm{~B}}, \mathrm{Gly}_{123 \mathrm{~B}}, \mathrm{Gly}_{342 \mathrm{~B}}, \mathrm{Gly}_{347 \mathrm{~B}}, \mathrm{Val}_{250 \mathrm{~B}}\right)\end{array}$ \\
\hline Compound 7 & 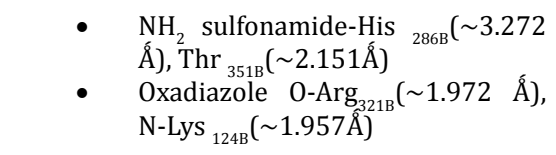 & 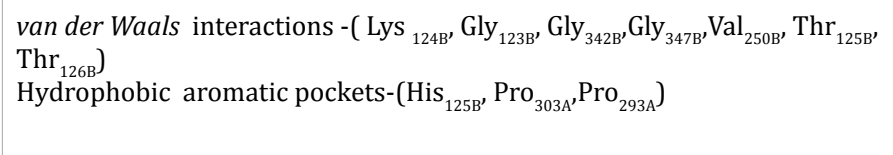 \\
\hline
\end{tabular}


Table 12: Binding interactions of active compounds with UDP-N[Mur E]PDB ID:2XJA (His-Histidine, Pro-Proline, Ser-Serine, Thr-Threonine, GlyGlycine, Tyr-Tyrosine, Arg-Arginine, Asn-Aspargine, Leu-Leucine,)

\begin{tabular}{|c|c|c|}
\hline Compound & Hydrogen bond interactions & Other interactions \\
\hline Phosphinate & - $\quad$ Phosphate (0)-Ser ${ }_{123 \mathrm{D}}(3.276)$ & $\begin{array}{l}\text { Hydrophobic aromatic pockets }\left(\mathrm{Tyr}_{311 \mathrm{D}}\right) \text {, van der Waals interactions of } \\
\text { methyl group with } \mathrm{Ser}_{370 \mathrm{D}}, \mathrm{Ser}_{123 \mathrm{D}}, \mathrm{Leu}_{346 \mathrm{D}} \text { and } \mathrm{Thr}_{127 \mathrm{D}}\end{array}$ \\
\hline Compound 6 & 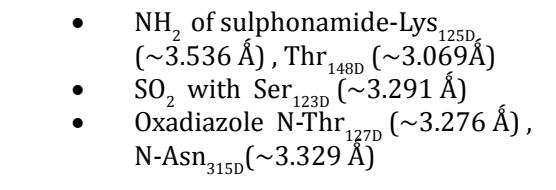 & $\begin{array}{l}\left.\text { Hydrophobic aromatic pockets-( } \operatorname{Tyr}_{311 \mathrm{D}} \text { and } \operatorname{Tyr}_{361 \mathrm{D}}\right) \\
\left.\text { van der Waals interactions -( } \operatorname{Ser}_{370 \mathrm{D}}, \operatorname{Ser}_{123 \mathrm{D}}, \operatorname{Leu}_{346 \mathrm{D}}, \operatorname{Thr}_{127 \mathrm{D}} \text { and } \operatorname{Arg}_{345 \mathrm{D}}\right)\end{array}$ \\
\hline Compound 7 & 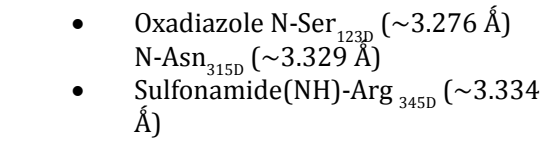 & $\begin{array}{l}\text { van der Waals interactions - }\left(\mathrm{Ser}_{370 \mathrm{D}}, \mathrm{Ser}_{123 \mathrm{D}}, \mathrm{Leu}_{346 \mathrm{D}}, \mathrm{Thr}_{127 \mathrm{D}} \text { and } \mathrm{Arg}_{345 \mathrm{D}}\right) \\
\left.\text { Hydrophobic aromatic pockets-(Tyr }{ }_{311 \mathrm{D}} \text { and } \operatorname{Tyr}_{361 \mathrm{D}}\right)\end{array}$ \\
\hline
\end{tabular}

\section{Conclusion}

The search for new antibacterial agents directed towards novel targets became highly imperative. Inspired by the literature survey about the potentiality of oxadiazole and sulphonamide moieties derivatives, a series of 4-Amino-N-[(5-phenyl-1,3,4oxadiazol-2-yl) methyl] substituted benzene-1-sulfonamides were designed. In silico evaluation including molecular properties like bioavailability, Lipinski's rule of five reflected the oral bioavailability of these compounds. Good druglikeness and bioactivity scores further indicated the probable potentiality of these compounds as future drugs. The presence of the two pharmacophoric scaffolds, oxadiazole and sulphonamide influenced the good bioactive scores. Compounds $6 \& 7$ with electron donating substituents showed positive scores as protease inhibitor and enzyme inhibitors.

Docking studies further supported the biological activities. The results indicated the possible inhibitory activity towards the Mur enzymes. The results also indicate the selectivity towards Mur A, Mur C, \& Mur E enzymes. Of all the compounds, compound 6 and compound 9 with isopropyl substitution exhibited the highest scores against all the three Mur enzymes. Compound 7 showed good binding interactions with Mur C and Mur E. Further research in this approach may be extended to decrease the in vitro evaluation on these enzymes. In addition, the synthesis of these compounds was also observed to be feasible. Thus this study will be promising in finding novel antimicrobial agents with the Mur enzyme inhibitory activity (or) peptidoglycan synthesis inhibitory activity and therapeutic potential as novel anti-TB drugs.

\section{Acknowledgement}

I sincerely thank the management of Krishna Teja Pharmacy College, Tirupati for providing necessary facilities for the above research work.

\section{References}

1. Hansch C, Sammes PG, Taylor JB. Comprehensive Medicinal Chemistry. 1990; Vol. 2, Pergamon Press: Oxford, Chap. 7.1.

2. Kanda Y, Kawanishi Y, Oda K, Sakata T, Mihara S, Asakura K, et al. Synthesis and structure-activity relationships of potent and orally active sulfonamide ETB selective antagonists. Bioorg. \& Med. Chem. 2001;9(4):897-907.

3. Stokes SS, Albert R, Buurman Ed T, Andrews B, Shapiro AB, Green OM, McKenzie, AR, Otterbein LR. Inhibitors of the acetyltransferase domain of $\mathrm{N}$-acetylglucosamine-1-phosphate-uridylyl transferase/ glucosamine-1-phosphate acetyl transferase (GlmU). Part 2: Optimization of physical properties leading to antibacterial aryl sulfonamides. Bioorg. \& Med. Chem. Lett, 2012; 22: 7019. (PMID:23099094)

4. Rahavi Ezabadi, Camoutsis C, Zoumpoulakis P, Geronikaki A, Sokovic M, Glamocilija J, et al. Sulfonamide-1,2,4-triazole derivatives as antifungal and antibacterial agents: Synthesis, biological evaluation, lipophilicity, and conformational studies. Bioorg. \& Med. Chem, 2007;16(3):1150-1161. Doi: 10.1016/j.bmc.2007.10.082.

5. Chibale K, Haupt H, Kendrick H, Yardley V, Saravanamuthu A, Fairlamb A H, et al. Antiprotozoal and cytotoxicity evaluation of sulfonamide and urea analogues of quinacrine. Bioorg. \& Med. Chem. Lett, 2001;11(19):2655-2657.

6. Roush WR, Cheng JM, KnappReed B, Alvarez Hernandez A, McKerrow JH, Hansell E, et al. Evaluation of Sulfonamide Derivatives of Dagenan Chloride as Lipoxygenase and $\alpha$-Glucosidase Inhibitors. Bioorg. Med. Chem. Lett. 2001;11:2759-2762.

7. Serradeil-Le Gal C. An overview of SR121463, a selective non-peptide vasopressin V2 receptor antagonist. Cardiovascular Drug Rev. 2001,19(3):201-14.

8. Natarajan A Guo, Harbinski F, Fan YH, Chen H, Luus L, Dierck J, Aktas H, Chorev M, Halperin JA. Novel arylsulfoanilide-oxindole hybrid as an anticancer agent that inhibits translation initiation. J. Med. Chem. 2004;47(21):4979-4982. doi:10.1021/jm0496234.

9. Brain CT, Paul JM, Loong Y, Oakley PJ. Novel procedure for the synthesis of 1,3,4-oxadiazoles from 1,2-diacylhydrazines using polymersupported Burgess reagent under microwave conditions. Tetrahedron Lett. 1999;40:3275-3278. doi: 10.1016/S0040-4039(99)00382-2 
10. Chandrakantha B, Prakash Shetty, Vijesh N, Nishitha I, Arun M Isloor. Synthesis, characterization and biological activity of some new 1,3,4-oxadiazole bearing 2-flouro-4- methoxy phenyl moiety. Eur J Med Chem. 2010;45:1206-1210. doi: 10.1016/j.ejmech.2009.11.046

11. Sangshetti JN, Chabukswar AR, Shinde DB. Microwave assisted one pot synthesis of some Novel 2,5-disubstituted 1,3,4-oxadiazoles as antifungal agents. Bioorg. Med Chem Lett. 2011;21(1):444-448. Doi :10.1016/j.bmcl.2010.10.120

12. de Oliveira CS, Lira BF, Barbosa-Filho JM, Lorenzo JG, de Athayde-Filho PF. Synthetic approaches and pharmacological Activity of 1,3,4-Oxadiazoles: A Review of the Literature from 2000-2012. Molecules. 2012;17(9):10192-10231. Doi:10.3390/ molecules170910192

13. Kumar B, Kumar A, Beheraand AK, Raj V. Latest Update on Pharmacological Activities of 1,3,4-Oxadiazole Derivatives. J Cell Sci Ther, 2016;7:233. doi:10.41 72/2157-7013.1000233

14. Om Prakash, Manoj Kumar, Rajesh Kumar, Chetan Sharma, Aneja KR. Hypervalent Iodine(III) mediated synthesis of novel unsymmetrical 2,5-disubstituted 1,3,4 oxadiazoles as antibacterial and antifungal agents. Eur J Med Chem. 2010;45:4252-4257. Doi:10.1016/j. ejmech.2010.06.023

15. Sudhamani H, Thaslim Basha Sk, Venkateswarlu N. Synthesis and characterization of new thiourea and urea derivatives of 6-fluoro3-(piperidin-4-yl) benzo[d] isoxazole: In vitro Antimicrobial and Antioxidant activity, J Chem Sci. 2015;127(10):1739-1746. doi:10.1007/s12039-015-0935-6

16. Chopra I, Storey C, Falla TJ, Pearce JH. Antibiotics, peptidoglycan synthesis and genomics: the chlamydial anomaly revisited. Microbiology. 1998;144: 2637-2678. Doi:10.1099/00221287-14410-2673.

17. Danial N N, Korsmeyer S J. Cell death: critical control points, Cell. 2004;116(2):205-219.

18. Douglas B Kitchen, Helene Decornez, John R Furr, Jurgen Bajorath. Docking and scoring in virtual screening for drug discovery: methods and applications. Nat Rev Drug Discov. 2004;3: 935-949. doi:10.1038/ $\operatorname{nrd} 1549$

19. Brooijmans N, Kuntz I D. Molecular recognition and docking algorithms. Ann Rev Biophys Biolmol. Struct. 2003;32:335-373. Doi: 10.1146/annurev. biophys.32. 110601. 142532.

20. Lipinski CA, LombardoF, Dominy BW, Feeney PJ. Experimental and computational approaches to estimate solubility and permeability in drug discovery and development settings. Adv Drug. Del Rev.1997;23:3-25. Doi: 10.1016/S0169-409X(96)00423-1

21. Lalitha P, Sivakamasundari S. Calculation of molecular lipophilicity and drug likeness for few heterocycles. Oriental J Chem. 2010;26:135141

22. Auger G, van Heijenoort J, Vederas JC, and Blanot D. Effect of analogues of diaminopimelic acid on the meso-diaminopimelate-adding enzyme from Escherichia coli. FEBS Lett. 1996;391:171-174. Doi: 10.1016/ S0014-5793(96)90569-4
23. Nicolle LE. Urinary tract infection: traditional pharmacologic therapies. Am J Med. 2002;113(1A): 35S-44S. doi: 10.1067/mda.2003

24.Zeng B, Wong KK, Pompliano DL, Reddy S, Tanner ME. A phosphinate inhibitor of the mesodiaminopimelic acid-adding enzyme (MurE) of peptidoglycan biosynthesis. J Org Chem. 1998;63(26):10081-10086.

25. Schonbrunn E, Eschenburg S, Luger K, Kabsch W, Amrhein N. Structural basis for the interaction of the fluorescence probe 8-anilino-1-naphthalene sulfonate (ANS) with the antibiotic target MurA. Proc Natl Acad Sci USA. 2000;97: 6345-6349. doi: 10.1073/ pnas. 120120397

26.Spraggon G1, Schwarzenbacher R, Kreusch A, Lee CC, Abdubek P, Ambing E, et al. Crystal structure of an UDP-N-acetylmuramatealanine ligase MurC (TM0231) from Thermotoga maritima at 2.3 $A{ }^{\circ}$ resolution. Proteins, 2004; 55(4):1078-1081. Doi: 10.1002/ prot. 20034

27. Strancar K, Boniface A, Blanot D, Gobec S. Phosphinate inhibitors of UDP-N-acetylmuramoyl-L-alanyl-D-glutamate: L-lysine ligase (MurE). Arch Pharm Chem Life Sci. 2007;340(3):127-134. Doi: 10.1002/ ardp.200600191

28. Chemaxon available at http:// www. chemaxon. com/ products/ marvin/marvinsketch. [last accessed on 2016 April 14]. Marvin Sketch 16.11.21, Developed by Chemaxon worldwide (USA, Europe, Asia) Pune, India, Advent Informatics, , info@adventinformatics.com

29. Dogne JM, Supuran CT, Pratico DJ. Adverse Cardiovascular Effects of the Coxibs. J Med Chem. 2005;48: 2251-2257. Doi: 10.1021/ jm0402059

30. Entrl P, Muhlbacher J, Rohde B, Selzer P. Web-based cheminformatics and molecular property prediction tools supporting drug design and development at Novartis. SAR QSAR Environ Res, 2003;14(15-6):321328.Doi:10.1080/ 1062936031000167391

31. Molinspiration Available at http://www.molinspiration.com [last accessed on 2016 Feb 8]. Founded in 1986 as a spin-off of Bratislava University, Nova ulica, SK-900 26 Slovensky Grob, Slovak Republic, used Molinspiration Fragment-based Virtual Screening Engine v2016.02

32. Molsoft Available at http://molsoft.com/mprop/ http://molsoft. com/mprop/ [last accessed on 2016 Oct 4]. Version 3.8-5,Developed by Molsoft L.L.C. 11199 Sorrento Valley Road, S209 San Diego CA 92121,info@molsoft.com

33. Rathish IG, Javed K, Ahmad S, Bano S, Alam MS, Pillai KK, Singh S, Bagchi V. Bioorg. Synthesis and antiinflammatory activity of some new 1,3,5-trisubstituted pyrazolines bearing benzene sulfonamide. Med Chem Lett. 2009;19(1):255-258. Doi: 10.1016/j.bmcl.2011.05.061

34.Swiss Dock available at http://swissdock.vital-it.ch /docking \#.[last accessed on 2016 Jun 25]. a free protein ligand docking web service powered by EADock DSS by the Molecular Modeling group of the Swiss Institute of Bioinformatics

35. Van Heijenoort J. Recent advances in the formation of the bacterial peptidoglycan monomer subunit. Nat Prod Rep. 2001; 18(5):503-519. Doi: 10.1039/A804532A 